\title{
Proposal to Disseminate the Knowledge of Tsunamis in the Caribbean Coast of Costa Rica, Central America
}

\author{
Mario Fernández Arce ${ }^{1,2,3}$, Daniel Solís', Juan Luis Porras ${ }^{4,5}$, Gino González \\ ${ }^{1}$ PREVENTEC, University of Costa Rica (UCR) \\ ${ }^{2}$ Escuela de Geografía-UCR \\ ${ }^{3}$ Centro de Investigaciones en Ciencias Geológicas-UCR \\ ${ }^{4}$ Escuela de Geología-UCR \\ ${ }^{5}$ Red Sismológica Nacional (RSN: ICE-UCR) \\ Email: mario.fernandezarce@ucr.ac.cr
}

Received July 2014

\begin{abstract}
This work is a proposal to spread the knowledge of tsunamis in the schools of the Caribbean coast of Costa Rica. Ignorance of basic information about tsunamis and the existing threat, could result in deaths in areas where tsunami occur. For this reason, we have implemented this project which is intended to inform the population of coastal schools of the natural threat and how to deal with it. It is expected to prepare the population to adequately face an emergency by tsunami and reduce its impact. The work will be done through information sessions, training workshops and the production of a video that will be used for a permanent training in schools. The selected schools are in the communities of Barra del Colorado, Barra the Tortuguero, Barra de Parismina, Puerto Limón, Cahuita, Puerto Viejo and Manzanillo.
\end{abstract}

\section{Keywords}

Tsunamis, Threat, Vulnerability, Disaster, Risk

\section{Introduction}

There is a tsunami threat in Costa Rica. The two coasts of this country have geological processes capable of generating local tsunamis [1]-[3]. Six tsunamis have been documented in the Caribbean coasts of Costa Rica and Panama from 1539 to the present. But, unfortunately, many people don't know this reality and there is, therefore, no adequate preparation to face this hazard. The 2004 Indonesia tsunami demonstrated that without knowledge of the phenomenon, the probability of becoming a victim of a tsunami increases. The death toll increases because people are not able to recognize the signs prior to the arrival of a tsunami. The 2011 Japan tsunami showed that the impact of a tsunami can go beyond what is expected by technical and scientific groups. To reduce the impact of a tsunami we must prepare the population to respond appropriately in an emergency. To ac- 
complish this goal, we visit the coasts, explaining and publicizing the phenomenon, eliminating myths, revealing realities and removing all the doubts. There is a need for very practical and concrete action to educate the population to respond and address the alerts on tsunamis. Although efforts have been made to educate coastal communities in the field of tsunamis, much training is still needed. Therefore, we will design a training that will include an evaluation of knowledge on tsunamis before and after the training.

Such an effort and preparation are required because Costa Rica is a country with great tourist potential, where the population in the coastal zones is increasing due to this development. The increase in population also increases the vulnerability and the risk of disaster. The need for preparation was evident on June 15, 2014, when a 5.4 earthquake, which took place in the Caribbean Sea about $380 \mathrm{~km}$ from the Nicaraguan coast, caused expectation and alarm in Puerto Limon. Due to that fear, several public institutions worried about evacuating their working centers.

Practical actions and concrete proposals seek to save lives by empowering the population to address and respond to the alerts that emanate from scientific groups. Although efforts have been made to educate coastal communities in the field of tsunamis [3]-[6], almost nothing has been done in the Caribbean side of Costa Rica. Therefore, it is time to make an intervention in this vulnerable and forgotten area. With hard work we hope to prepare the population of the Caribbean coastal schools to adequately address the tsunami threat.

\section{Antecedents}

Fernández et al. [1] investigated the threat by tsunamis in Central America and reported 6 local tsunamis that occurred in the Caribbean coasts of Costa Rica and Panama between 1798 and 1991. All these tsunamis were generated by reverse earthquakes due to compressive forces associated with the North Panama Deformed Panama Belt (NPDB). As you can see in Table 1, the Ms magnitude of such earthquakes varied from 6.9 to 7.9. The generated tsunamis were small.

The effects of these documented tsunamis are small. They include agitation of the sea and floods. The 1916 tsunami produced a wave of more than 1 meter high that brought canoes and debris $200 \mathrm{~m}$ inland and destroyed storage tanks. The 1882 earthquake is the largest that has occurred in Central American so far. This great earthquake caused a tsunami that greatly affected the islands, which were flooded by the waves of the tsunami. This event caused between 75 and 100 victims. It is very likely that this tsunami arrived at Costa Rica, although no damage was reported in this country.

According to Fernández and Alvarado [3], the 1991 earthquake generated tsunami waves confirmed along a $160 \mathrm{~km}$ segment of coastline, from Matina-Costa Rica, to Bocas del Toro, Panama. They struck the coast within 5 - 15 minutes of the earthquake [7]. Such waves produced maximum height and landward penetration in Panama of 3 and $150 \mathrm{~m}$ respectively. The inundation decreased rapidly about $25 \mathrm{~km}$ northwest of the Panama-Costa Rica border. With regard to the damage, the tsunami left layers of sand and debris on the ground and dead fish in some places of the coast. Some residents were frightened and ran to high sites. Panama was more affected by the tsunami than Costa Rica.

Regarding the management tsunami disasters in Costa Rica, we are running a project that aims to bring tsunami scientific information through training workshops to the staff and students of coastal schools across the country. Since 2005, meetings have been held with teachers from the Ministry of Public Education to give them basic and clear information on tsunamis.

Table 1. Information of earthquakes and tsunamis of the Caribbean side of Costa Rica and Panama. Source: Fernandez et al., 2000.

\begin{tabular}{|c|c|c|c|c|c|c|}
\hline \multicolumn{4}{|c|}{ Earthquake Data } & \multicolumn{3}{|c|}{ Tsunami Data } \\
\hline$\#$ & Time & Location & Magnitude & Location & Run-up (m) & Magnitude \\
\hline 1 & $1798-0222$ & Northwest of Limon & & Matina, Costa Rica & & -1 \\
\hline 2 & $1822-0507$ & Southeast of Limon & 7.6 & Matina, Costa Rica & & -1 \\
\hline 3 & 1882-0907 & San Blas Islands, Panama & 7,9 & San Blas Island, Panama & 3 & 1 \\
\hline 4 & $1904-1220$ & Southeast of Limon & 7.3 & Bocas del Toro, Panamá & & \\
\hline 5 & $1916-0426$ & Southwest of Limon & 6.9 & Bocas del Toro, Panamá & 1.3 & 0 \\
\hline 6 & $1991-0422$ & South Limon & 7.6 & Bocas del Toro, Panamá & 3 & 1 \\
\hline
\end{tabular}


In 2007 an inter-institutional group (The National Emergency Office, UCR, Municipalidad de San José and the Japan International Cooperation Agency) executed the project "Promotion of Tsunamis in Puntarenas (the most important Costa Rican port in the Pacific)" which produced teaching guides for teachers and students about the tsunami threat and also a flip chart on the topic. We are currently spreading knowledge of tsunamis in the schools of the Costa Rican Pacific coast [8]. A toolkit of tsunamis is being developed for the students of Costa Rican elementary schools [9].

\section{The Caribbean Coast of Costa Rica and Its Vulnerability}

The Costa Rican Caribbean coast is rectilinear and flat with many natural channels and swamps that make the coastal communities more vulnerable and difficult to evacuate. This situation is more pronounced in the northwest since there is no relief close to the coast. The communities of Barra del Colorado, Parismina and Tortuguero only have access by rivers. Access to Limón, Cahuita, Puerto Viejo and Manzanillo is overland and some of these towns have access to nearby highlands.

The Caribbean coast of Costa Rica is very attractive because of its lush vegetation, beautiful beaches, wetlands and coastal forests, lagoons, wildlife refuges, nesting grounds of sea turtles, national parks and natural channels. We have decided to spread the knowledge of tsunamis in the schools of the following communiites: Barra del Colorado, Tortuguero, Barra de Parismina, Limón, Cahuita, Puerto Viejo and Manzanillo (Figure 1). The Barra del Colorado Community is a coastal town near both the border with Nicaragua and the Barra del Colorado Wildlife Refuge which has 92,000 hectares of wet lands and rainforests that are habitat for many flora and native fauna of the country.

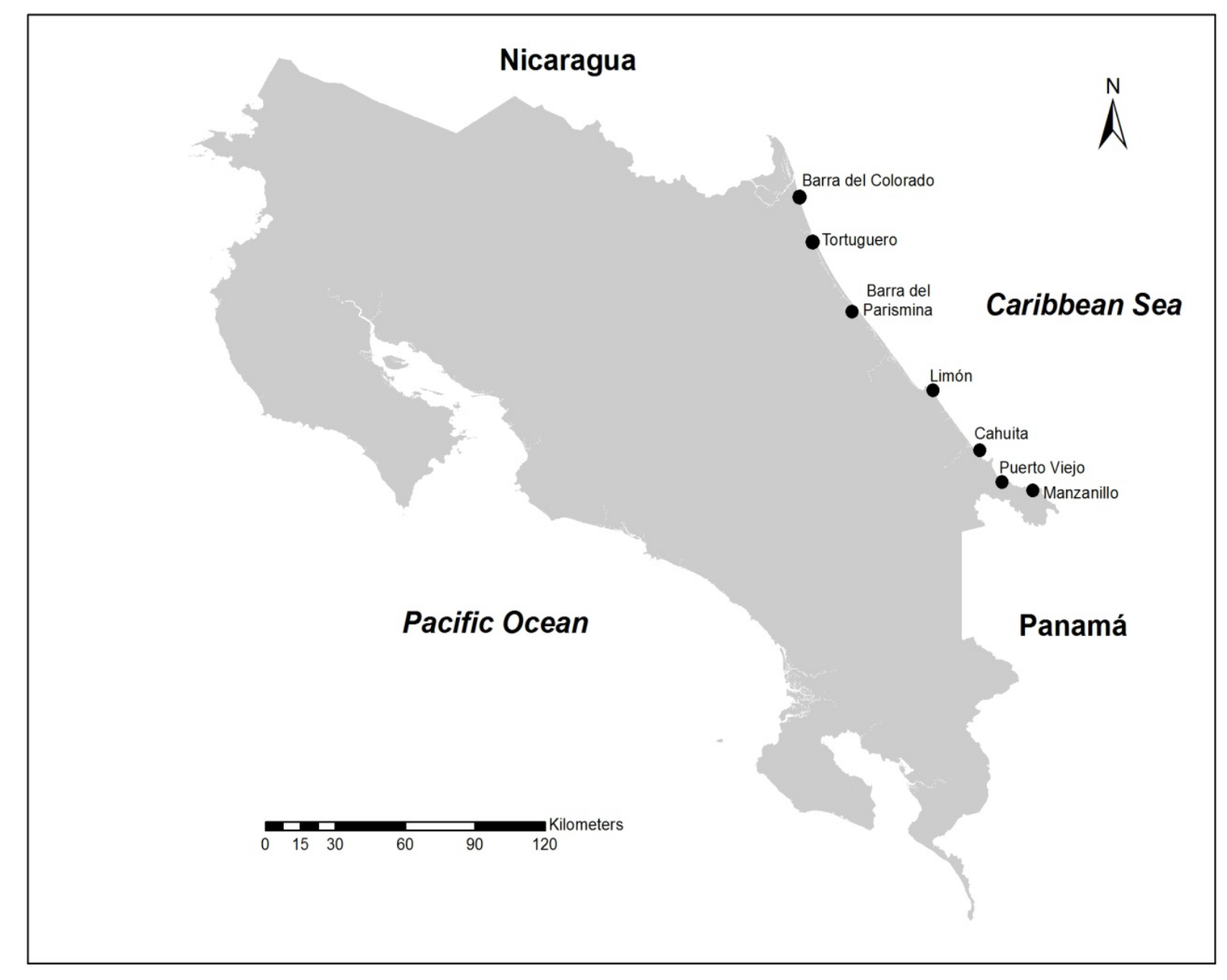

Figure 1. Map showing the communities where the promotion of tsunami will take place. 
Tortuguero is located in the wonderful Tortuguero National Park. The small town is truly a touristic destination. The site is very attractive because of the nesting of green sea turtles. Its population is estimated to be almost 1500 inhabitants. The Barra del Parismina is a town built on one side of the Parismina River. It is estimated that some 400 people live there. Its main economic activities are ecotourism and sport fishing.

Limon is the largest city and most important commercial port of Costa Rica. The city is separated from the sea by a boardwalk called "tajamar" (cutwater). It was connected to the nation's capital in 1890 by a railroad made to promote exports of coffee to Europe. Its economic activities have been based for a long time in the production of banana and livestock. Limon is characterized by having the largest black population nationwide. The climate of this province is mainly humid and rainy for most of the year. Its population is over 100,000 inhabitants.

Cahuita is a tourist place of special interest which has a beautiful beach of yellow sand and coral formations. There is a national park of 22,400 hectares near the community. The main economic activities of the population have traditionally been fishing and farming, although in recent years they have lost importance to tourism, whose main attractions are its beaches of coconut palms (Black Beach) and the Cahuita National Park.

Puerto Viejo is a coastal community and a popular tourist destination. It is known in the surfing community as having the largest and most powerful wave in Costa Rica, called "Salsa Brava". It is also a site of beautiful beaches such as Playa Chiquita, Playa Negra and Punta Uva, which are some of the most spectacular beaches of Costa Rica. Puerto Viejo offers hotels, restaurants and services closer to the border with Panama. The inhabitants of the village are mostly of Costa Rican origin, with a substantial population of Jamaican descent, as well as a good number of Europeans who have migrated to the region. Manzanillo is a popular place for boating. The Nacional Refuge Gandoca-Manzanillo is a protected area of great beauty near Manazanillo.

\section{The Proposal}

Our proposal is to bring knowledge of tsunamis to the population of Caribbean coastal schools of Costa Rica, which implies the following:

1) Presentation of the project to the authorities of the Ministry of Public Education of Costa Rica and coordination with the regional supervisors to start the work in schools.

2) Initial visit at the schools to measure how much the students and staff know about the natural threat and give an informative talk on tsunamis. To measure this knowledge we apply a test with the following questions: 1 -What is a tsunami? 2-What are its causes? 3-What is the maximum speed of the tsunami? 4-What is the maximum height of the most recent tsunami? 5-What are the effects of tsunamis? 6-Does a tsunami threat exist in Costa Rica? 7-What are the basic rules to deal with a tsunami? During the first visit we will schedule the next visits.

3) After the first visit will begin training workshops for students.

4) Once the students have a good level of knowledge on tsunamis, they will answer the aforementioned questions during interviews that will be recorded with a television camera and the resulting clips will be used to make a video about tsunamis. This video will be used later to disseminate the knowledge of tsunamis in the educational center and therefore, technical groups will no longer need to do training at the school. This video will make work easier and more effective for schoolteachers in charge of disaster risk management.

\section{Present and Future Actions}

As part of the activities of the project we have visited the schools of Manzanillo, Puerto Viejo, Cahuita, and Limón (Figure 2). We visited schools of these towns to know their physical condition and explore the interest of the principal and teachers in the topic. On previous occasions we visited Parismina.

Both the schools of Manzanillo and Puerto Viejo are located 100 meters from the beach on a flat area. The school of Puerto Viejo, unlike other schools, is near high relief which offers relatively safe places in the event of a tsunami. However, power lines with high voltage pass in front of this school and must be taken into account when evacuating the center. Cahuita's school is also on a flat area and less than 50 meters from the beach so it requires much preparation to face an emergency by tsunami. The school Tomás Guardia, located in Puerto Limón, is perhaps the best constructed of all the schools visited in the Caribbean. It is farther from the beach and has a second floor which could serve as a temporary shelter in the event of a tsunami.

In the Northern Caribbean tsunami emergency management is complicated because there is no access by land 
to its towns. The towns are often set between the sea, rivers and natural channels which increase the risk of flooding by tsunamis and rivers overflow. The school of Parismina is near areas flooded by the Parismina River (Figure 3).

In the following months we will complete the work in the selected schools. At the same time, we will work on a tool kit of tsunamis which will include a pamphlet, a board game and a video animation that will be designed, produced and validated in at least five schools of the Caribbean.

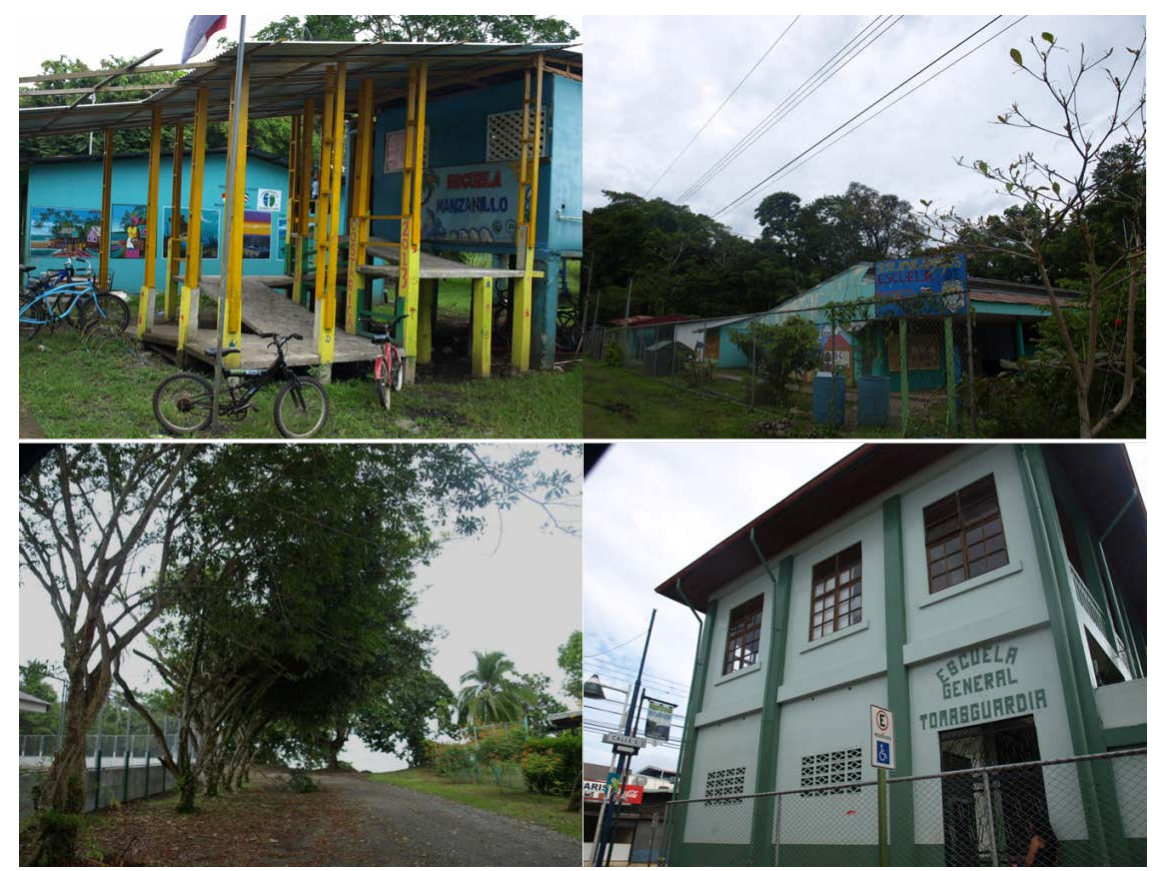

Figure 2. The schools of Manzanillo, Puerto Viejo, Cahuita (left down corner) and Tomás Guardia in Limón. Courtesy of Oscar Sojo.

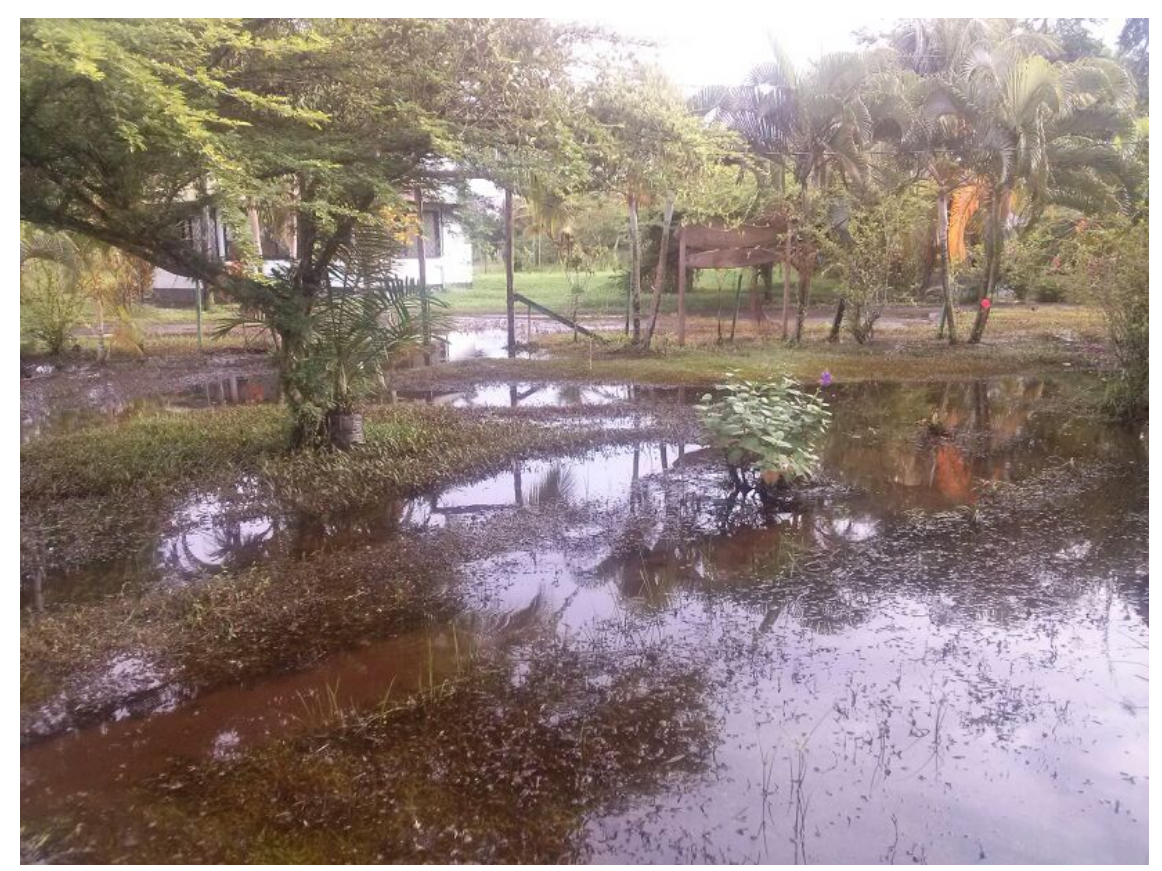

Figure 3. Flooded áreas near the school of Parismina (to the right, not shown) generated by overflow of the Parismina River. 


\section{Final Comments}

Although there is no record of large, destructive tsunamis in the Caribbean coast of Costa Rica, the tsunami threat is real. Previous studies have revealed that local tsunamis can be generated on this coast. The coast is very attractive and flat which increases the vulnerability of coastal residents and tourists. In addition, lack of access by land to some places makes it difficult to handle emergencies caused by tsunamis in those areas. For all these reasons, the population of Costa Rica Caribbean coast needs attention and preparation to face an eventual emergency by tsunamis. We have initiated such preparation and hope to complete it in the course of the coming months and perhaps years.

\section{Acknowledgements}

We would like to express our gratitude to Paula Dunbar for taking the time to review, correct and improve our manuscript. Thanks also to Laura Kong for her invaluable assistance to our group. Jonnathan Reyes helped in preparing Figure 1.

\section{References}

[1] Fernández, M., Molina, E., Havskov, J. and Atakan, K. (2000) Tsunamis and Tsunami Hazards in Central America. Natural Hazards, 22, 91-116. http://dx.doi.org/10.1023/A:1008102600622

[2] von Huene, R., Ranero, C. and Watts, P. (2004) Tsunamigenic Slope Failure along the Middle American Trench in Two Tectonic Setting. Marine Geology, 203, 303-317.

[3] Fernández, M. and Alvarado, G. (2005) Tsunamis and Tsunami Preparedness in Costa Rica, Central America. ISET Journal of Earthquake Technology, 42, 203-212.

[4] Fernández, M., Calderón, C. and Castellón, M. (2005) Los tsunamis, una oportunidad para la aplicación de conocimiento científico. Imprenta Nacional.

[5] Alvarado, G., Fernández, M., Madrigal, R. and Romero, L. (2007) Información sobre la amenaza por de tsunami. Guía Didáctica para la Enseñanza de Tsunamis. Agencia de Cooperación Japonesa (JICA).

[6] Fernández, M. (2014) La preparación ante tsunamis en el distrito de Cóbano, Puntarenas, Costa Rica. Salud Ocupacional HOY, 6.

[7] Denyer, P., Arias, O. and Personius, S. (1994) Generalidades Sobre Los Efectos Geológicos Del Terremoto De Limón, Revista Geológica de América Central, Vol. Esp. Terremoto De Limón, 29-38 (in Spanish).

[8] González, G., Porras, J. and Fernández, M. (2014) Promotion of Knowledge of Tsunamis in Coastal Schools of Costa Rica. The Science of Tsunami Hazards (Submitted).

[9] Porras, J., González, G. and Fernández, M. (2014) A Tsunami Kit for Elementary Schools of Costa Rica. The Science of Tsunami Hazards (Submitted). 